\title{
Microstructure and Properties of Magnesium Alloys Working at Elevated Temperatures
}

Jan Serak, Milena Voderova, Dalibor Vojtech, Pavel Novak

Institute of Chemical Technology, Prague, Department of Metals and Corrosion Engineering, Technická 5, 16628 Prague 6, Czech Republic. E-mail: serakj@vscht.cz

Most of magnesium alloys are usually used for applications at ambient temperature. The significant decrease in mechanical properties is observed already at the temperatures higher than $150^{\circ} \mathrm{C}$. This is the reason for the effort to prepare a new low-priced magnesium based alloys with improved mechanical properties at elevated tem-peratures, e.g. for components of combustion engines. The microstructure and mechanical properties of selected commercial magnesium alloys AZ31, EZ23, ZE41 and WE43 with relatively new MRI153 alloy for use at elevat-ed temperature were compared. Brinell hardness, yield strength and tensile strength at the temperatures of 20,150 and $200^{\circ} \mathrm{C}$ were studied. It was found, that relatively low-priced MRI153 alloy appears to be very good alternative alloy for use at elevated temperatures.

Keywords: magnesium alloys; mechanical properties

\section{Acknowledgement}

The presented results were obtained within the frame of the research project GA CR No. P108/12/G043.

\section{References}

[1] KAINER, K. (2003) Magnesium - Alloys and Technologies. ISBN 9783527305704.

[2] International Magnesium Association. http://www.intlmag.org/MgBibliographicDatabase.html (reffered 14.9. 2012).

[3] HERMAN, A. (2005) Výhody použití Mg slitin v porovnáni s ostatnimi konstrukčnimi materiály. [online], č. 10 (reffered 14.9. 2012), p. 92.

[4] http://www.mmspektrum.com/clanek/vyhody-pouziti-mg-slitin-vporovnani-s-ostatnimi-konstrukcnimi-materialy.html.

[5] ČECH, J.; et al. (2012) Použití hořčíkových slitin ve slévárenství.

[6] http://www.explat.cz/files/pouziti_mg_slitin_ve_slevarenstvi.pdf(reffered 14.9. 2012).

[7] KAINER, K. (2010) Corrosion of Magnesium and its Alloys; Elsevier.

[8] ZHU, S., et al. (2010) The relationship between microstructure and creep resistance in die-cast magnesium rare earth alloys. Scripta Materialia, vol. 63, p. 698-703.

[9] YOO M.K., KIM J.J., SHIN K.S., KIM N.J. (2002) Effect of Second Phases on the High temperature Mechanical Properties of Squeeze Cast Mg-Al Alloys, Magnesium Technology 2002, TMS.

[10] MARTIN, J. (2006) Concise encyclopedia of the structure of materials.

[11] ZHU, S., et al. (2006) Creep and Rupture Properties of a Squeeze-Cast Mg-Al-Ca Alloy. Metall. Mater. Trans. A, 2006, vol. 37 A, p. $1222-1229$.

[12] ZHU, S., et al. (2008) Creep properties of a Mg-Al-Ca alloy produced by different casting technologies. Mater. Sci. Eng., A, vol. 483, p. 583-586.

[13] VON BUCH, F.; et al. (2012) New die - casting alloy MRII53 for power train applications.

[14] http://iweb.tms.org/Mg/magtech2002/014.pdf (reffered 14.9. 2012)

[15] YU, S., et al. (2010) Microstructure and mechanical properties of friction stir welding of AZ31B magnesium alloy added with cerium. Journal of Rare Earths, vol. 28, no. 2, s. 316., ISBN 0080451276, 9780080451275.

[16] RZYCHON T., KIELBUS A. (2006) Microstructure of WE43 casting magnesium alloy JAMME, vol.21, p. 31-34.

[17] SEDIAKO D., SHOOK S. (2010) Application of Neutron Diffraction in Characterization of Texture Evolution during HighTemperature Creep in Magnesium Alloys, In: Canadian Nuclear Society Meeting, Montreal.

[18] LUKOVICS I., MALACHOVA M. (2012) Laser Machining of Chosen materials, In: Manufacturing Technology, vol.12, No.12, p. 38-42

[19] NOVAKOVA-MARCINCINOVA L., JANAK M. (2012) Application of Progressive Materials for Rapid Prototyping Technology, Manufacturing Technology vol.12, No.12, p. 75-79

[20] KRYNKE M., SELEJDAK J., BORKOWSKI S. (2012) Diagnosis and Damage of Bearings, Manufacturing Technology vol.12, No.13, p. 140-144 